\title{
Association of human lymphocyte antigens with obstructive airways disease after bone marrow transplantation
}

\author{
DAVID SPANER MD PhD FRCPC, JEFFREY LIPTON MD PhD FRCPC, \\ CHARLES K CHAN MD FRCPC FCCP FACP \\ Bone Marrow Transplant Service, Department of Medicine, Princess Margaret Hospital, and \\ Division of Respiratory Medicine, The Wellesley and Toronto Hospitals, Toronto, Ontario
}

D Spaner, J Lipton, CK Chan. Association of human lymphocyte antigens with obstructive airways disease after bone marrow transplantation. Can Respir J 1996;3(1):41-46.

BACKGROUND: Obstructive airways disease (OAD) is a known complication of allogeneic bone marrow transplantation. The etiology of OAD is unknown but is probably multifactorial. The identification of a significant human lymphocyte antigen (HLA) association with the development of OAD might offer some insight into its pathogenesis and serve as a marker to identify prospectively patients at risk for developing OAD.

OBJECTIVE: The major histocompatibility antigen (MHC) associations of OAD post-allogeneic bone marrow transplantation were studied to determine whether particular subsets of patients are more susceptible to this syndrome. POPULATION: Twenty-one of 244 consecutive patients with allogeneic transplants performed between 1980 and 1987 were identified as developing OAD after having had normal pulmonary function tests before transplant. Thirtynine controls were selected on the basis of normal pulmonary function tests pre- and post-transplant and comparable follow-up periods.

METHODS: The study was a retrospective case-control study. Gene frequencies of the HLA-A and -B types in the patients and controls were compared and a relative risk of OAD with a given HLA allele was calculated.

RESULTS: There was a significant correlation of the development of OAD with the presence of the MHC antigen, HLA-B12 $(44,45)$.

CONCLUSIONS: These data support the idea that patients who express the HLA-B12 $(44,45)$ antigen are at higher risk for the development of OAD post bone marrow transplantation. However, the findings are based on retrospective analysis and accordingly should be considered tentative until followed by larger and preferably prospective studies to confirm the findings. (Pour le résumé, voir page 42) Key Words: Bone marrow transplantation; Human lymphocyte antigens; Obstructive airways disease 


\section{Association des antigènes HLA à la maladie pulmonaire obstructive après une greffe de moelle osseuse}

CONTEXTE : La maladie pulmonaire obstructive (MPO) est une complication connue de la greffe de moelle osseuse allogénique. L'étiologie de la MPO reste inconnue mais est probablement multifactorielle. L'identification d'une association significative entre les Human leucocyte antigens (HLA) et le développement de la maladie pulmonaire obstructive pourrait permettre d'en comprendre sa pathogenèse et servir de marqueur pour identifier d'une manière prospective les patients susceptibles de développer une MPO.

OBJECTIF : Les associations du complexe majeur d'histocompatibilité (CMH) avec la MPO suite à une greffe allogénique de moelle osseuse ont été étudiées pour déterminer si des sous-groupes de patients particuliers sont plus susceptibles de développer ce syndrome.

POPULATION : Sur 244 patients consécutifs ayant reçu une greffe allogénique entre 1980 et 1987, 21 ont été identifiés comme étant en train de développer une MPO. Les épreuves de fonction respiratoire de ces patients étaient toutes normales avant la transplantation. Trente-neuf témoins ont été choisis sur la base d'épreuves de fonction respiratoire normales avant et après la greffe et de périodes de suivi comparables.

MÉTHODES : Il s'agissait d'une étude rétrospective cas/témoins. On a comparé les fréquences des gènes du groupe HLA-A et HLA-B chez les patients et les témoins, puis on a calculé le risque relatif de MPO associé à un allèle HLA donné.

RÉSULTATS : La corrélation entre le développement de la MPO et la présence de l'antigène du CMH, HLA-B12 $(44,45)$ était significative.

CONCLUSIONS : Ces données suggèrent que les patients qui expriment l'antigène HLA-B12 $(44,45)$ sont plus susceptibles de développer une MPO à la suite d'une greffe de moelle osseuse. Cependant, ces résultats sont basés sur une analyse rétrospective et devraient, comme il se doit, être considérés comme étant provisoires jusqu'à ce que de plus grandes études, de préférence prospectives, soient menées pour confirmer ces résultats.
A irways obstruction has been reported in approximately $10 \%$ of allogeneic bone marrow transplant (BMT) recipients (1-3). The pathology of the disease is thought to be the same as for bronchiolitis obliterans, although pathological material is not available in all patients. This lung disease is thought to be a manifestation of chronic graft-versus-host disease (GVHD) through an immunological attack on lung epithelium. Other pathogenic mechanisms have not been ruled out. For example, obstructive airways disease (OAD) may be due to a persistent viral infection in the immunodeficient state of chronic GVHD, to recurrent aspiration from esophageal involvement in chronic GVHD, or to drug or radiation toxicity from the preparative regimen before BMT.

The identification of a significant human lymphocyte antigen (HLA) association with the development of OAD might offer some insight into its pathogenesis. Diseases with specific HLA associations are felt to be 'autoimmune' in nature (4). Alternatively, HLA molecules may not be able to present peptides from microbial proteins with the result that an infectious process can proceed unchecked (4).

A significant HLA association might also serve as a marker to identify prospectively those patients who are at risk for developing OAD and to allow for prediction of the severity of the ensuing disease.

For these reasons, the HLA types of patients with OAD post-BMT were contrasted with an appropriate control population in this study.

\section{PATIENTS AND METHODS}

Two hundred and thirty-four patients had allogeneic BMT performed at the Ontario Cancer Institute, Toronto, Ontario between 1979 and 1987. One-year event-free survival in these patients is $70 \%(5)$. By examination of patient charts, serial pulmonary function tests, lung biopsies and autopsy materials, if available, 21 patients were identified who developed OAD consistent with bronchiolitis obliterans postBMT. The criteria for OAD to warrant inclusion in the study
TABLE 1

Control data

\begin{tabular}{lcc}
\hline & $\begin{array}{c}\text { Whole population } \\
(\mathbf{n = 2 3 4 )}\end{array}$ & $\begin{array}{c}\text { Controls } \\
(\mathbf{n}=\mathbf{3 9})\end{array}$ \\
\hline Male:female ratio & $1.3: 1$ & $2.0: 1$ \\
Age (years) & 29 (range 16-49) & 30 (range 17-41) \\
Chronic GVHD (\%) & 68 & 67 \\
Disease state: & & \\
CML (\%) & 36 & 38 \\
AML (\%) & 30 & 28 \\
ALL (\%) & 20 & 20 \\
Aplastic anemia (\%) & 10 & 10 \\
MM (\%) & 2 & 3 \\
\hline
\end{tabular}

ALL Acute lymphocytic leukemia; AML Acute myelogenous leukemia; CML Chronic myelogenous leukemia; GVHD Graft-versus-host disease; MM Multiple myeloma

were, first, normal pulmonary function tests pretransplant; and second, development of airflow obstruction, as defined by forced expiratory volume in $1 \mathrm{~s}\left(\mathrm{FEV}_{1}\right)$ less than $80 \%$ of predicted; less than $15 \%$ improvement in the flow rates with inhaled beta-agonist; residual volume greater than $120 \%$ predicted; and maximal expiratory flow rate at 50\% vital capacity $\left(\mathrm{V}_{50}\right)$ less than $65 \%$ predicted. Some of these patients also underwent helium-oxygen maximal expiratory flow studies in order to localize obstruction at the small airways.

Seven of 21 patients fulfilling the above criteria for OAD had pathological lung specimens confirming the presence of bronchiolitis obliterans.

As controls, 39 patients from the same period were chosen from those who had serial surveillance pulmonary function tests without evidence of OAD. Routinely, at the authors' centre, pulmonary function tests are done every three months for the first year and then yearly thereafter depending on symptoms. Controls and cases were followed for comparable periods of time. The following matching criteria were used: genetic age \pm five years; survival longer than 40 days post- 
transplant; and normal pulmonary function tests pre- and post-BMT. The details of the controls are shown in Table 1 and their HLA types in Table 2. Patients with acute lymphocytic leukemia were treated with vincristine $(2 \mathrm{mg})$, prednisone $(100 \mathrm{mg} /$ day for five days), L-asparaginase $(30,000$ units/day for five days) and cyclophosphamide $(60 \mathrm{mg} / \mathrm{kg} /$ day for two days). Patients with severe aplastic anemia received cyclophosphamide (50 mg/kg/day for four days) and 300 cGy of total body irradiation. Several patients received busulfan ( $1 \mathrm{mg} / \mathrm{kg}$ every $6 \mathrm{~h}$ for a total of 16 doses) and cyclophosphamide $(60 \mathrm{mg} / \mathrm{kg} /$ day for two days) in a 'high risk' protocol for advanced diseases.

GVHD prophylaxis: Most patients received methotrexate (days 1,3,6 and 11) post-transplant and prednisone starting on day 9 post-BMT $\left(40 \mathrm{mg} / \mathrm{m}^{2}\right.$ for 40 days tapering over 120 days). Several patients received methotrexate as above plus cyclosporin $(12.5 \mathrm{mg} / \mathrm{kg} /$ day orally or $5 \mathrm{mg} / \mathrm{kg} /$ day intravenously starting on day -1 pretransplant for 40 days and then tapering over 42 days).

Development of GVHD was treated by a variety of approaches including high dose methylprednisolone, oral cyclophosphamide, azathioprine and cyclosporin.

Pulmonary function tests: Patients were assessed with pulmonary function tests pretransplant and at least at day 100 and yearly, or more frequently depending on symptoms. Pulmonary function tests were done with standard laboratory equipment. Flow volume curves were generated using a model 750 wedge spirometer (Med Science Electronics Incorporated, Missouri) combined with an XY recorder (Hewlett Packard Corp, Massachusetts) equipped with a $1 \mathrm{~s}$ timer. Total lung capacity and residual volume were determined by body plethysmographic techniques using a PK Morgan body plethysmograph (Kent, United Kingdom) and by singlebreath helium dilution techniques using a PK Morgan modular lung analyzer.

HLA typing: HLA-A and HLA-B were typed by a standard two-stage lymphocytotoxicity method, using lymphocytes separated from fresh samples of peripheral blood. Well-characterized antisera, capable of recognizing all common A, B and C specificities, including most splits, were used. In 1984, HLA-B12 was split into B44 and B45 (6). B12 and B44 are used equivalently in this paper since about half of the present study's cases were typed before 1984 when this split occurred. Other relevant splits include A9 $(23,24)$, A10 $(25,26)$, AW19(29,30,31,32), B5(51,52), B15(W62,W63), B16(38,39), B17(W57,258) and B40(W60,W61) (6). Class II HLA (HLA-DR) typing was not routinely available during this period, and a mixed lymphocytic reaction was performed to indicate minimum antigen disparity between donor and host.

Patient performance: The Karnofsky scale (7) was used in an attempt to compare the severity of the lung disease with other aspects of the patient's chronic GVHD. Patients were rated according to their degree of impairment from their lung disease, and then another rating was made for the severity of other aspects of their chronic GVHD, excluding lung status. This latter rating included morbidity from other affected organs, such as liver disease or the effects of medication
TABLE 2

HLA-A and -B Gene frequencies

\begin{tabular}{|c|c|c|c|c|}
\hline & $\begin{array}{c}\text { Controls } \\
(n=39)\end{array}$ & $\begin{array}{l}\text { Cases } \\
(n=21)\end{array}$ & $\begin{array}{c}\text { Whole group } \\
(n=60)\end{array}$ & $\begin{array}{c}\text { General } \\
\text { population* }\end{array}$ \\
\hline \multicolumn{5}{|c|}{ HLA-A } \\
\hline 1 & 15.4 & 23.8 & HLA-A & 14.2 \\
\hline 2 & 26.9 & 26.2 & 26.7 & 28.9 \\
\hline 2 & 14.1 & 14.3 & 14.2 & 13.2 \\
\hline 11 & 5.1 & 2.4 & 4.2 & 6.3 \\
\hline 23 & 1.3 & 2.4 & 1.7 & 1.4 \\
\hline 24 & 9.0 & 4.8 & 7.5 & 10.3 \\
\hline 26 & 2.6 & 0 & 1.7 & 3.2 \\
\hline 28 & 6.4 & 2.4 & 5.0 & 4.7 \\
\hline 29 & 1.3 & 7.1 & 3.3 & 2.9 \\
\hline 30 & 6.4 & 2.4 & 5.0 & 3.5 \\
\hline 31 & 2.6 & 2.4 & 2.5 & 2.9 \\
\hline 32 & 1.3 & 2.4 & 1.7 & 3.9 \\
\hline \multicolumn{5}{|c|}{ HLA - B } \\
\hline 7 & 10.3 & 14.3 & 11.7 & 11.5 \\
\hline 8 & 6.4 & 7.1 & 6.7 & 9.6 \\
\hline 13 & 2.6 & 0 & 1.7 & 2.9 \\
\hline 18 & 6.4 & 9.5 & 7.5 & 5.5 \\
\hline 27 & 2.6 & 2.4 & 2.5 & 3.4 \\
\hline 35 & 11.5 & 4.8 & 9.2 & 10.5 \\
\hline 37 & 1.3 & 2.4 & 1.7 & 1.6 \\
\hline 38 & 2.6 & 2.4 & 2.5 & 2.5 \\
\hline 39 & 1.3 & 0 & 0.8 & 2.0 \\
\hline 44 & 5.1 & 26.2 & 12.5 & 12.3 \\
\hline 51 & 6.4 & 4.8 & 5.8 & 6.2 \\
\hline 52 & 5.1 & 0 & 3.3 & 2.0 \\
\hline 57 & 2.6 & 9.5 & 5.0 & 2.9 \\
\hline 60 & 3.8 & 4.8 & 4.2 & 3.8 \\
\hline 61 & 2.6 & 0 & 1.7 & 2.1 \\
\hline 62 & 5.1 & 2.4 & 4.2 & 6.1 \\
\hline 64 & 1.3 & 9.5 & 4.2 & 1.1 \\
\hline
\end{tabular}

*North American Caucasian population (data from reference 6). HLA Human lymphocyte antigen

needed to control ongoing chronic GVHD such as infections or osteoporosis from prolonged steroid use. A rating of 0 was given to the organ system mainly responsible for the patients' death.

Statistical analysis: $\chi^{2}$ analysis was performed using a Minitab program. The level of significance was determined from the appropriate statistical tables. Probabilities were corrected by multiplying by the number of HLA -A and -B antigens studied (a total of 29) as previously described (8). $\mathrm{P}<0.05$ was considered to be significant.

\section{RESULTS}

OAD post-BMT has been reported in approximately $10 \%$ of cases (1-3). Our finding of 21 in 234 cases is in agreement with this observation. The clinical course of the patients is detailed in Table 3.

Gene frequencies of the most common HLA-A and -B types are shown in Table 2 for the patients with OAD and the control group. The gene frequency in the whole study population is compared with that of the Caucasian North Ameri- 
TABLE 3

Bone marrow transplant patient data

\begin{tabular}{|c|c|c|c|c|c|c|c|c|c|c|c|c|c|}
\hline \multirow{2}{*}{$\begin{array}{l}\text { Patient } \\
\text { number }\end{array}$} & \multirow[b]{2}{*}{ HLA-A } & \multirow[b]{2}{*}{ HLA-B } & \multirow{2}{*}{$\begin{array}{c}\text { Age } \\
\text { (years) }\end{array}$} & \multirow[b]{2}{*}{ Diagnosis } & \multirow[b]{2}{*}{ Sex } & \multirow{2}{*}{$\begin{array}{l}\text { cGVHD } \\
\text { onset } \\
\text { (day) }\end{array}$} & \multirow{2}{*}{$\begin{array}{l}\text { OAD } \\
\text { onset } \\
\text { (day) }\end{array}$} & \multicolumn{3}{|c|}{$\begin{array}{l}\text { Worst pulmonary } \\
\text { function tests } \\
\text { (\% predicted) }\end{array}$} & \multicolumn{2}{|c|}{$\begin{array}{l}\text { Karnofsky } \\
\text { score }\end{array}$} & \multirow[b]{2}{*}{ Outcome } \\
\hline & & & & & & & & $\mathrm{FEV}_{1}$ & $V_{50}$ & RV & Lung & Other & \\
\hline 35 & 25,33 & 44,17 & 41 & Other & $\mathrm{F}$ & 126 & 207 & 52 & 29 & 133 & 90 & 0 & Died of pneumonia \\
\hline 46 & 28 & 12,14 & 19 & ALL & $\mathrm{F}$ & 354 & 811 & 29 & 71 & 201 & 80 & 0 & $\begin{array}{l}\text { Died of pneumonia and } \\
\text { GI GVHD }\end{array}$ \\
\hline 50 & 1,23 & 12,14 & 22 & CML & $\mathrm{F}$ & 100 & 756 & 66 & 47 & 121 & 100 & 80 & $\begin{array}{l}\text { Alive with severe eye } \\
\text { GVHD }\end{array}$ \\
\hline 67 & 3,24 & 44,18 & 37 & CML & M & 100 & 170 & 48 & 42 & 72 & 80 & 80 & $\begin{array}{l}\text { Alive with severe skin } \\
\text { GVHD }\end{array}$ \\
\hline 98 & 11,29 & 44,62 & 24 & CML & $\mathrm{F}$ & 110 & 356 & 16 & 4 & 363 & 0 & 80 & Died of lung disease \\
\hline 108 & 1,24 & 18,44 & 26 & AML & M & 261 & 381 & 26 & 7 & 320 & 40 & 80 & $\begin{array}{l}\text { Alive with severe lung } \\
\text { disease }\end{array}$ \\
\hline 114 & 1,2 & 8,44 & 17 & CML & M & 136 & 187 & 22 & 12 & 234 & 0 & 90 & Died of pneumonia \\
\hline 129 & 1,2 & 44,18 & 33 & CML & $\mathrm{F}$ & 52 & 1200 & 62 & 93 & 141 & 90 & 80 & $\begin{array}{l}\text { Alive with severe skin } \\
\text { disease }\end{array}$ \\
\hline 140 & 3,29 & 14,12 & 31 & CML & $\mathrm{F}$ & 187 & 187 & 66 & 31 & 138 & 90 & 0 & Died of relapse \\
\hline 141 & 1,2 & 12,17 & 22 & CML & $\mathrm{F}$ & - & 96 & 65 & 27 & 153 & 90 & 90 & Died of relapse \\
\hline 179 & 1,32 & 12,37 & 19 & AML & M & 354 & 410 & 63 & 61 & 64 & 90 & 80 & $\begin{array}{l}\text { Alive with severe skin } \\
\text { and eye disease }\end{array}$ \\
\hline 12 & $2,-$ & 35,40 & 20 & CML & M & 161 & 1669 & 58 & 83 & 147 & 80 & 70 & $\begin{array}{l}\text { Alive with severe skin } \\
\text { disease }\end{array}$ \\
\hline 96 & 3,30 & 7,27 & 30 & CML & $\mathrm{F}$ & 161 & 738 & 70 & 54 & 131 & 80 & 70 & $\begin{array}{l}\text { Alive with severe osteo- } \\
\text { porosis from steroids }\end{array}$ \\
\hline 119 & 1,3 & 7,8 & 16 & AA & M & 88 & 102 & 30 & 11 & 179 & 80 & 90 & Alive \\
\hline 136 & 1,3 & 7,16 & 40 & CML & M & - & 53 & 66 & 42 & 117 & 80 & 80 & $\begin{array}{l}\text { Alive with severe skin } \\
\text { disease }\end{array}$ \\
\hline 152 & 1,2 & 8,14 & 37 & AML & M & 100 & 109 & 48 & 21 & 282 & 0 & 90 & Died of lung disease \\
\hline 170 & 2,29 & 7,14 & 29 & CML & M & 100 & 111 & 20 & 6 & 255 & 20 & 20 & Died of relapse \\
\hline 186 & 1,2 & 5,35 & 22 & $\mathrm{CML}$ & M & 88 & 117 & 15 & 4 & 181 & 0 & 80 & Died of lung disease \\
\hline 190 & 2,3 & $\begin{array}{r}7 \\
W 60\end{array}$ & 35 & CML & M & 92 & 100 & 29 & 11 & 231 & 0 & 70 & Died of lung disease \\
\hline 212 & 2,2 & 17,18 & 32 & AML & $\mathrm{F}$ & 300 & 300 & 31 & 11 & 232 & 60 & 80 & $\begin{array}{l}\text { Alive with severe lung } \\
\text { disease }\end{array}$ \\
\hline 251 & 2,31 & $\begin{array}{r}51 \\
\text { W57 }\end{array}$ & 31 & AML & $M$ & 100 & 180 & 70 & 50 & 107 & 80 & 80 & $\begin{array}{l}\text { Alive with severe } \\
\text { steroid side effects }\end{array}$ \\
\hline
\end{tabular}

AA Aplastic anemia; ALL Acute lymphocytic leukemia; AML Acute myelogenous leukemia; BMT Bone marrow transplant; CML Chronic myelogenous leukemia; FEV 1 Forced expiratory volume in $1 \mathrm{~s} ;$ GI Gastrointestinal; GVHD Graft versus host disease; HLA Human lymphocyte antigen; OAD Obstructive airways disease; RV Residual volume; $V_{50}$ Maximal expiratory flow rate at $50 \%$ vital capacity

can population in general (6). It is important that they be fairly close in order to prevent spurious HLA associations due to the small study populations involved, as is the case.

The most significant association is seen with B12 $(44,45)$. Eleven of 21 OAD patients had B12 or B44 while only four of 39 controls without OAD had this antigen. The relative risk (RR) of OAD with B12(44) is 9.6 with $\chi^{2}=12.92$ and $\mathrm{P} \leq 0.001$ and corrected $\mathrm{P} \leq 0.03$. Since the numbers of subjects in the two groups was small, with Yates' correction (9) $\chi^{2}=9.4$ with $\mathrm{P}<0.005$; the association remains significant.

The association rests on the fact that the gene frequency of B44 in the control population is only 5.1 compared with that in the general population of 12.3 It is unlikely that this low frequency arose by chance since the total gene frequency in the controls and cases was 12.5, similar to the frequency in the general population.

For reassurance that the association of $\mathrm{B} 44$ with $\mathrm{OAD}$ was not a spurious result due to an unfortunate choice of the con- trol population, the patient group was compared with all patients who developed chronic GVHD post-BMT at the Princess Margaret Hospital between 1980 and 1986. These patients have been described elsewhere (5). Ninety-two such patients were identified, of which 19 were previously identified patients and 73 did not get OAD post-BMT. Thirteen patients with HLA-B44 were found in the latter group. In other words, of 92 patients with chronic GVHD, 19 had OAD and 73 did not. Eleven of 19 patients with OAD expressed B12 while 13 of 73 without OAD expressed the B12 allele. $\mathrm{RR}=6.2$ for $\mathrm{OAD}$ with $\mathrm{B} 12(44)$, with $\chi^{2}=13.5$ and $\mathrm{P} \leq 0.001$. Therefore, even compared with this group, the association of HLA-B44 with the development of OAD post-BMT remains significant.

Insignificant associations were seen with B17 and A29, as shown in Table 4. The association of A29 may be because A29 and B44 show haplotype linkage in the population (4). An insignificant protective association was seen with B35. 
HLA and lung disease in marrow transplantation

TABLE 4

Human lymphocyte antigen (HLA) associations with obstructive airways disease post bone marrow transplantation

\begin{tabular}{|c|c|c|c|c|c|c|}
\hline HLA & $\begin{array}{c}\text { Patients } \\
\text { n (\%) }\end{array}$ & $\begin{array}{c}\text { Controls } \\
\text { n (\%) }\end{array}$ & Relative risk & $\chi^{2}$ & $P$ value & $\begin{array}{c}\text { Corrected } \\
\mathrm{P} \text { value }\end{array}$ \\
\hline $\mathrm{B} 12(44,45)$ & $11(52 \%)$ & $4(10 \%)$ & 9.6 & 12.92 & $\leq 0.001$ & $\leq 0.03$ \\
\hline B17 $(57,58)$ & $4(19 \%)$ & $2(5 \%)$ & 4.4 & 2.94 & $\geq 0.05$ & - \\
\hline A 29 & $3(14 \%)$ & $1(3 \%)$ & 6.3 & 3.01 & $\geq 0.05$ & - \\
\hline B35 & $2(10 \%)$ & $9(23 \%)$ & 0.3 & 1.68 & $\geq 0.1$ & - \\
\hline
\end{tabular}

The 11 patients with $\mathrm{OAD}$ and $\mathrm{B} 12$ or $\mathrm{B} 44$ were compared with the remainder who did not carry the B12 $(44,45)$ allele to determine whether their disease was any different in its clinical course. The results are shown in Table 5. Although no significant differences, except for sex, were noted, some interesting trends emerged. The patients with HLAB12 $(44,45)$ tended to have a milder disease in terms of higher $\mathrm{FEV}_{1}$ and $\mathrm{V}_{50}$ and lower residual volume. They were less disabled in terms of their lung disease, and the obstructive symptoms occurred later after transplant. However, they were more subjectively disabled in terms of active skin, liver or gastrointestinal symptoms of chronic GVHD. More women than men with OAD had the B12 $(44,45)$ antigen.

\section{DISCUSSION}

Previous studies (2) have identified chronic GVHD and prolonged methotrexate treatment as risk factors for OAD post-BMT. Holland and co-workers (3) reported an association of OAD with chronic GVHD and hypogammaglobulinemia. However, it was not clear whether the humoral immunodeficiency was simply a consequence of chronic GVHD or represented the immune defect that resulted in the development of OAD. Patients with primary hypogammaglobulinemia get bronchiectasis and OAD but not the pathological picture seen in BMT (10). The only models in which bronchiolitis obliterans in experimental animals is reproducible involve clinically irrelevant methods such as intratracheal instillation of activated T cells (11). A model of GVHD in immunodeficient C.B-17-scid mice, where effects of conditioning and infection are minimized (12), also does not show any lung involvement in GVHD. Chronic GVHD is likely a $\mathrm{T}$ cell-mediated process like the bronchiolitis obliterans that occurs in lung transplant patients undergoing rejection of their graft. The bronchiolitis obliterans that occurs after BMT in patients with chronic GVHD may also have an immunopathogenesis.

Other possibilities for the causes of OAD post-BMT include characterized or uncharacterized infectious processes in the immunosuppressed state that is present post-BMT, recurrent aspiration due to sclerodermatous esophageal involvement in chronic GVHD, and drug or radiation toxicity from the preparative regimen in BMT. The methotrexate association has already been noted.

There has recently been interest in the possibility that cytomegalovirus (CMV) infections are responsible for OAD post-BMT (13). Of our patients, only BMT patients 212 and 136 had documented CMV infections as shown by a positive
TABLE 5

Comparison of lung disease in patients with and without HLA-B12 $(44,45)$

\begin{tabular}{lcc}
\hline Patients & $+\mathbf{B} 12(\mathbf{n = 1 1})$ & $-\mathbf{B} 12(\mathbf{n}=10)$ \\
\hline Age (years) & $26.4 \pm 7.6$ & $29.3 \pm 6.96$ \\
$\%$ Female & 64 & $20^{*}$ \\
$\begin{array}{l}\text { Onset of lung disease } \\
\text { (day post-BMT) }\end{array}$ & $432.8 \pm 18.8$ & $437.9 \pm 479.9$ \\
Worst pulmonary function test & & \\
$\quad$ FEV 1 & $46.8 \pm 18.8$ & $43.7 \pm 20.1$ \\
$\quad V_{50}$ & $38.5 \pm 26.6$ & $29.3 \pm 25.2$ \\
$\quad$ Residual volume & $176.3 \pm 91.0$ & $186.2 \pm 58.1$ \\
Karnofsky rating & & \\
$\quad$ For lung & $68.2 \pm 35.4$ & $48.0 \pm 36.0$ \\
$\quad$ For other organ disease & $60 \pm 36.9$ & $73.0 \pm 19.0$ \\
\hline * $\chi^{2}=4.073, P \leq 0.05$. The error is the standard error in the mean. BMT \\
Bone marrow transplantation; HLA Human lymphocyte antigen
\end{tabular}

culture of CMV or a rise in antibody titre. Patient $212 \mathrm{had}$ CMV pneumonitis several months before the development of biopsy-proven bronchiolitis obliterans. At the time of his open lung biopsy CMV was not found. The second patient was treated successfully for systemic CMV infection with gancyclovir about two years before the onset of OAD. All CMV cultures were negative at onset of his lung disease.

In this paper, we report an association of OAD post-BMT with HLA-B12 $(44,45)$. Previously Storb et al (14) reported an association of HLA-B8 with acute GVHD. Recently Smyth et al (15) showed an association between HLA-B44 and acute GVHD in an Australian population. Holmes and Whittaker (16) showed an association of HLA-DR4 with chronic GVHD in the South Wales population. However an HLA association with organ-specific GVHD has not, to our knowledge, previously been reported. Different target organs in GVHD, including the lung, liver, skin and gastrointestinal tract, may well have different HLA associations accounting, in part, for patient variation in presentation. The form of bronchiolitis associated with rheumatoid arthritis has been reported to have an HLA association that is not with B44 (17).

There may well be a stronger association between OAD post-BMT and the expression of HLA with HLA-DR. Until recently, class II typing has not been as complete as class I typing in our patients. More data with more complete HLA typing for individual patients are needed before a possible class II major histocompatibility complex association with OAD post-BMT can be determined. 
This study suffers from the obvious drawback that it is a retrospective analysis of a small number of patients. However, the model is consistent in that the control population is representative of the entire BMT population and the study population is representative of the Caucasian North American population for HLA gene frequency.

Many of the patients with OAD and B12/44 came from the early years of our transplant program. If the incidence of B12 in all referred patients was high initially and has decreased over time, the incidence of OAD has decreased over time for unrelated reasons, and the majority of the controls were chosen from more recent years, then the association of

ACKNOWLEDGEMENTS: We thank Dr G Fyles and Dr HA Messner for access to patient records and Dr Robert A Phillips for helpful review of the manuscript. We also thank Dr M Kramer and Dr J Theodore of Stanford University for supplying the HLA types on 65 heart-lung transplant patients. David Spaner was supported by fellowships from the Medical Research Council of Canada and the National Cancer Institute of Canada.

\section{REFERENCES}

1. Chan CK, Hyland RH, Hutcheon M, et al. Small airways disease in recipients of allogeneic bone marrow transplants. Medicine 1987;66:327-40.

2. Clark JG, Schwartz DA, Fluornoy N, et al. Risk factors for airflow obstruction in recipients of bone marrow transplants. Ann Intern Med 1987;107:648-56.

3. Holland HK, Wingard JR, Beschorner WE, et al. Bronchiolitis obliterans in bone marrow transplantation and its relationships to chronic graft vs host disease and low serum IgG. Blood 1988;72:621-7.

4. Germain RN. Antigen processing and presentation. In: Paul WE, ed. Fundamental Immunology. New York: Raven Press, 1993:629-76.

5. Fyles GM, Messner HA, Lockwood G, et al. Long term results of bone marrow transplantation for patients with AML, ALL, and CML prepared with single dose total body irradiation of $500 \mathrm{cGy}$ delivered with a high dose rate. Bone Marrow Transplant 1991;8:453-63.

6. Tsujii K, Aizawa M, Sasuzuki T, eds. HLA 1991. Proceedings of the Eleventh Histocompatibility Workshop and Conference. New York: Oxford University Press, 1992.

7. Karnofsky DA, Abelmann WH, Craver LF, et al. The use of nitrogen mustards in the palliative treatment of carcinoma. Cancer 1948;1:634-56.

8. Dunn OJ. Multiple comparisons among means. Am J Stat Assoc 1961;56:52-64.
B12 with OAD would simply be an artifact. This is unlikely because the numbers of controls for the time periods 197981, 1982-84, and 1985-87 were 9,13 and 17, respectively, while the numbers of cases for the same time periods were 4 , 10 and 7.

Finally, there are similarities between the bronchiolitis that occurs post-BMT and post heart-lung transplantation (18). Preliminary analysis reveals that there is no association of bronchiolitis post lung transplant with HLA type, however. One possibility for the lack of an HLA association in lung transplantation may be the absence of rigorous matching of HLA alleles of the donor and host that occurs in BMT.

9. Rosner B. Fundamentals of Biostatistics, 4th edn.Belmont: Dunbury Press, 1994:355.

10. Rosen FS. The primary specific immunodeficiencies. In: Lachmann PJ, Peters DKP, Rosen FS, Walport MJ, eds. Clinical Aspects of Immunology. Boston: Blackwell Scientific Publications, 1993:1271-786.

11. Streilein JS, Lipsom MF, Hart DA, Darder A. Graft versus host reaction in the lung. Transplantation 1981;32:38-44.

12. Phillips RA, Spaner DE. The scid mouse: mutation in a DNA repair gene creates recipients useful for studies on stem cells, lymphocyte development and graft-versus-host disease. Immunol Rev 1991;124:63-8.

13. Chien JM, Chan CK, Chamberlain D, et al. Cytomegalovirus pneumonia in allogeneic bone marrow transplantation - an immunopathological process? Chest 1990;98:1034-7.

14. Storb R, Prentice RL, Hansen JA, Thomas EB. Association between HLA-B antigens and acute graft versus host disease. Lancet 1983;ii:816-9.

15. Smyth LA, Herrman RP, Christiansen FT, et al. Major histocompatibility complex influences the development of acute graft-versus-host disease in MHC-matched adult allogeneic bone marrow transplantation. Transplant Proc 1993;25:1276-8.

16. Holmes JA, Whittaker JA. Histocompatibility antigen DR4 is associated with chronic GVHD in the South Wales population. Br J Haematol 1989;73:424.

17. Sweatman MC, Mackwick JR, Charles PJ, et al. Histocompatibility antigens in adult obliterative bronchiolitis with or without rheumatoid arthritis. Dis Markers 1986;4:19-26.

18. Glanville AR, Baldwin JC, Burke CM, et al. Obliterative bronchiolitis after heart-lung transplantation: apparent arrest by augmented immunosuppression. Ann Intern Med 1987;107:300-4. 


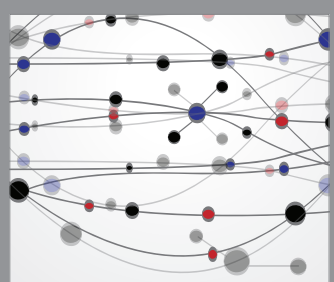

The Scientific World Journal
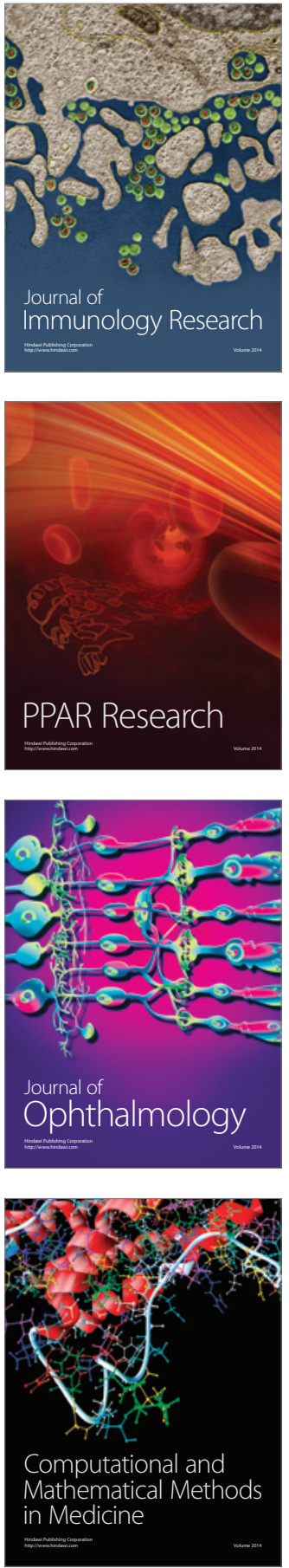

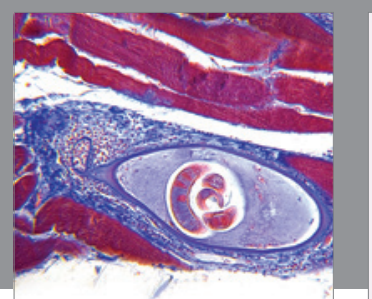

Gastroenterology Research and Practice

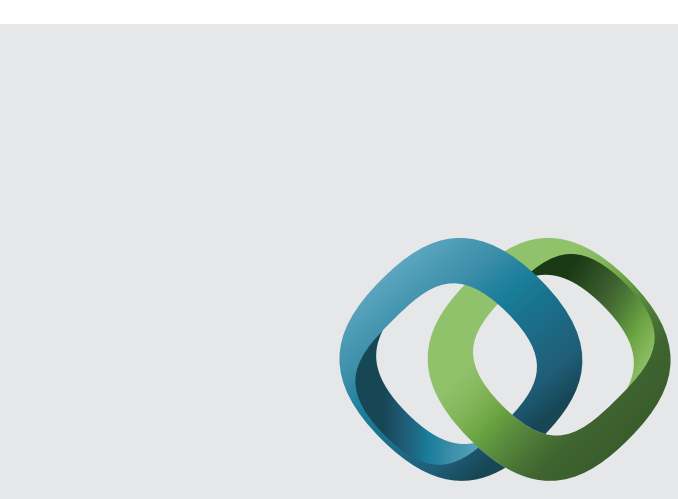

\section{Hindawi}

Submit your manuscripts at

http://www.hindawi.com
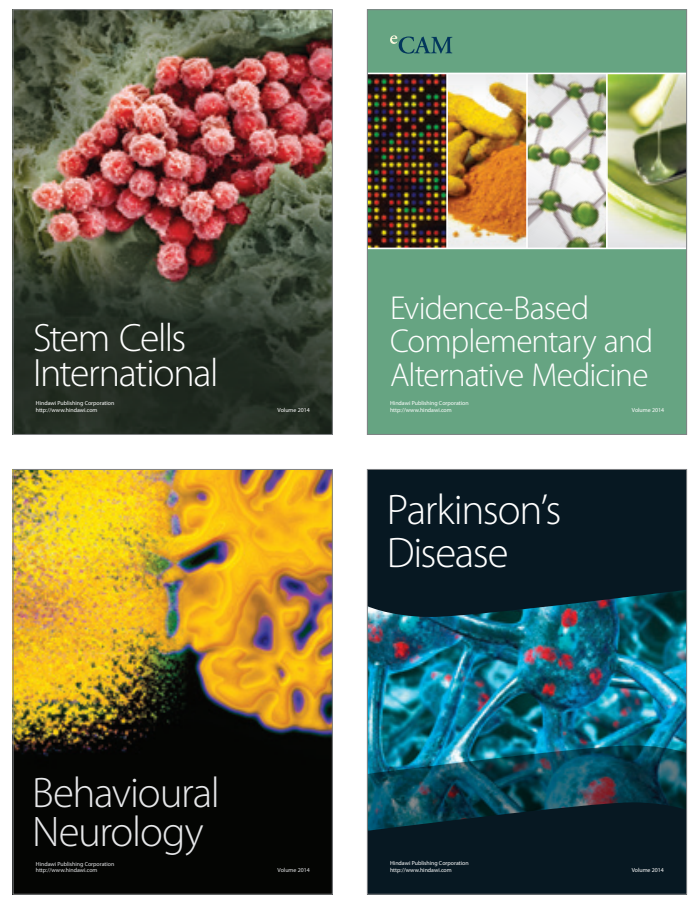
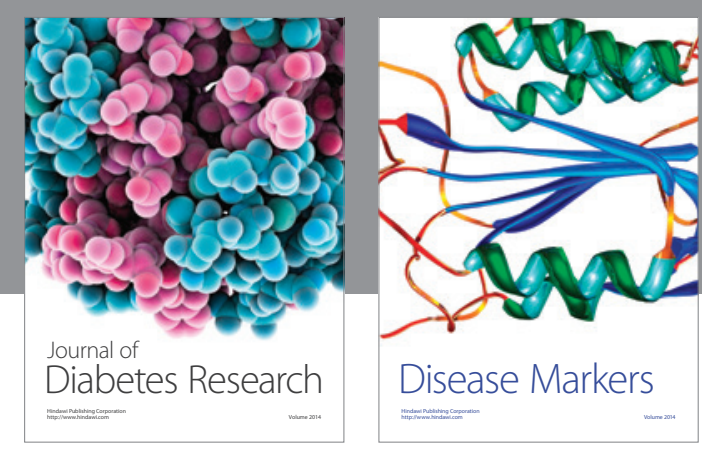

Disease Markers
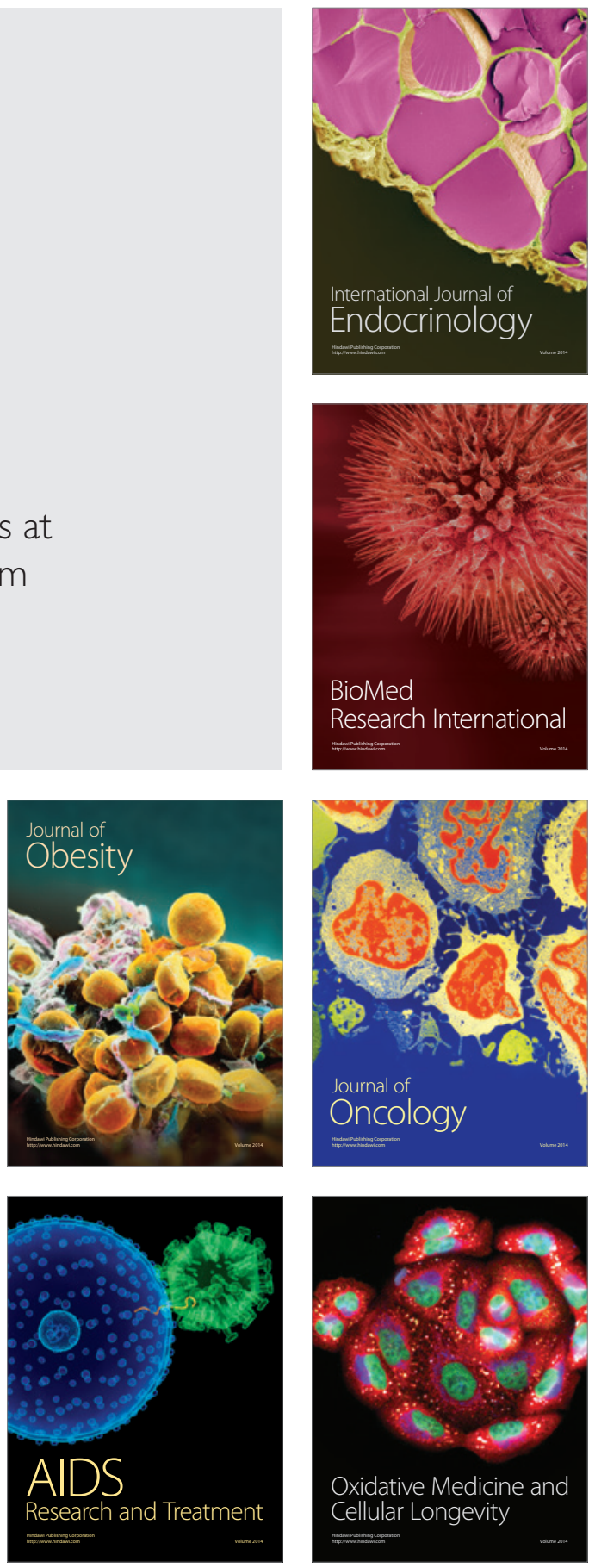